\title{
IMPLEMENTASI PAKET ONE HUSBAND ONE CLIENT UNTUK MENINGKATKAN KEPATUHAN IBU HAMIL MENGKONSUMSI TABLET FE DI PRAKTIK MANDIRI BIDAN FITRIANI
}

\author{
Fidyah Aminin ${ }^{1 *}$, Dewi Mey Lestanti Mukodri ${ }^{1}$ \\ ${ }^{1}$ Poltekkes Kemenkes Tanjungpinang \\ *email: fidyahaminin@yahoo.com
}

\begin{abstract}
Anemia is one of the biggest and most difficult macro nutritional problems overcome that occurs in many pregnant women throughout the world. Given the harmful effects it is necessary to prevent it by giving iron tablets to pregnant women. The role and function of the family is very important in providing motivation, monitoring health and reminding them to consume drugs. Therefore, it is necessary to provide assistance and supervision to take Fe tablets by the husband to pregnant women who are taking Fe tablets. The Community Service aims to increase the knowledge of pregnant women 's husbands regarding anemia and prevention of anemia, improve the assistance of husbands for pregnant women who consume Fe tablets and increase adherence of pregnant women to consume Fe tablets. The target of the activity is pregnant women and husbands of pregnant women. The method used in this activity is in the form of assistance and health education using leaflet media. This activity was carried out in one of the Independent Practice Midwives in the Tanjungpinang City area of Riau Islands, namely Midwife Fitriani and carried out by 2 midwife health workers assisted by the Tanjungpinang Health Department Midwifery Department student.
\end{abstract}

Keywords: One Husband One Client, Compliance, Anemia

\begin{abstract}
ABSTRAK
Anemia merupakan salah satu masalah gizi makro terbesar dan tersulit diatasi yang banyak terjadi pada ibu hamil di seluruh dunia. Mengingat dampaknya yang membahayakan maka perlu pencegahan dengan memberikan tablet zat besi pada ibu hamil. Peran dan fungsi keluarga sangat penting dalam memberikan motivasi, memantau kesehatan dan mengigatkan dalam mengkonsumsi obat. Oleh karena itu perlu dilakukan pendampingan dan pengawasan minum tablet Fe oleh suami terhadap ibu hamil yang sedang mengkonsumsi tablet Fe. Pengabdian Kepada Masyarakat ini bertujuan untuk meningkatkan pengetahuan suami ibu hamil mengenai anemia dan pencegahan anemia, meningkatkan pendampingan suami terhadap ibu hamil yang mengkonsumsi tablet Fe dan meningkatkan kepatuhan ibu hamil mengonsumsi tablet Fe. Sasaran kegiatan adalah ibu hamil dan suami ibu hamil. Metode yang digunakan pada kegiatan ini berupa pendampingan dan pendidikan kesehatan menggunakan media leaflet. Kegiatan ini dilaksanakan di salah satu Praktik Mandiri Bidan yang ada di wilayah Kota Tanjungpinang Kepulauan Riau yaitu Bidan Fitriani dan dilakukan oleh 2 orang tenaga kesehatan bidan yang dibantu oleh mahasiswa Jurusan Kebidanan Poltekkes Kemenkes Tanjungpinang.
\end{abstract}

Kata Kunci : One Husband One Client, Kepatuhan, Anemia 


\section{PENDAHULUAN}

Anemia dalam kehamilan berdampak membahayakan bagi ibu dan janin. Anemia pada ibu hamil dapat meningkatkan resiko terjadinya perdarahan postpartum. Anemia yang terjadi sejak awal kehamilan dapat menyebabkan resiko terjadinya prematur (Mochtar, 2008).Anemia yang sering terjadi pada ibu hamil yaitu anemia defisiensi besi dengan prevalensi $51 \%$ di seluruh dunia. Mengingat dampaknya yang membahayakan maka perlu pencegahan anemia dengan memberikan tablet zat besi pada ibu hamil (Astuti, D. 2014). Pemerintah Indonesia sudah melakukan upaya penanggulangan anemia, diantaranya dengan memberikan Tablet Tambah Darah (TTD) pada wanita hamil. Pendistribusian TTD juga telah dilakukan melalui Puskesmas dan Posyandu.

Melalui program pemberian tablet besi ini diharapkan dapat menurunkan angka kejadian anemia pada ibu hamil di Indonesia. Namun ternyata hasilnya belum begitu memuaskan, terlihat dari angka prevalensinya yang masih tinggi. Menurut Penelitian Sebelumnya rendahnya tingkat kepatuhan ibu hamil dalam mengkonsumsi suplemen besi merupakan salah satu penyebabnya (Purwaningsih dkk, 2004). Niven (2002) menyebutkan bahwa salah stau faktor yang dapat mempengaruhi kepatuhan penderita dalam menjalani program pengobatan adalah dukungan keluarga. (Neherta, dkk.2010). Namun selama ini belum adanya pemantau khusus untuk konsumsi tablet fe juga mempengaruhi kepatuhan ibu hamil.

Peran dan fungsi keluarga sangat penting di saat salah satu anggota keluarga mengalami masalah kesehatan. Mereka dapat memberikan motivasi kepada pasien, mengingatkan pasien minum obat dan memantau kesehatannya. Keluarga ikut serta memotivasi dan mengingatkan pasien minum obat (Julianti, dkk.2015). Oleh karena itu perlu dilakukan pendampingan dan pengawasan minum tablet Fe oleh suami terhadap ibu hamil yang sedang mengkonsumsi tablet $\mathrm{Fe}$ dengan memberikan "Paket one husband one client untuk meningkatkan kepatuhan ibu hamil mengkonsumsi tablet Fe di Kota Tanjungpinang"

\section{METODE}

1. Persiapan Kegiatan

a. Survey tempat pelaksanaan kegiatan pengabdian masyarakat di Praktek Mandiri Bidan Fitriani, Ganet, Kota Tanjungpinang

b. Pembuatan Proposal pengabdian masyarakat dengan judul Implementasi Paket One Husband One Client untuk meningkatkan kepatuhan ibu hamil mengkonsumsi tablet Fe di Praktik Mandiri Bidan Fitriani, , Ganet, Kota Tanjungpinang

c. Perijinan tempat pengamdian masyarakat di Praktik Mandiri Bidan Fitriani, , Ganet, Kota Tanjungpinang

d. Mencari dan menyusun materi mengenai anemia pada kehamilan, upaya mencegah anemia dan pendampingan ibu hamil mengkonsumsi tablet Fe

e. Persiapan alat dan bahan untuk pengabdian masyarakat 
2. Pelaksanaan Kegiatan

\begin{tabular}{|c|c|c|c|c|c|}
\hline No & Kegiatan & Metode & Waktu & Alat & Sasaran \\
\hline 1 & $\begin{array}{l}\text { Pendidikan } \\
\text { kepada suami ibu hamil } \\
\text { tentang anemia dan } \\
\text { pencegahannya }\end{array}$ & $\begin{array}{l}\text { Ceramah } \\
\text { dan Tanya } \\
\text { Jawab }\end{array}$ & $\begin{array}{l}17 \text { Oktober } \\
2018\end{array}$ & Leaflet & $\begin{array}{l}\text { Suami ibu } \\
\text { hamil }\end{array}$ \\
\hline 2 & $\begin{array}{l}\text { Kunjungan rumah untuk } \\
\text { memastikan pendampingan } \\
\text { suami terhadap ibu hamil } \\
\text { ketika mengkonsumsi tablet } \\
\text { tambah darah }\end{array}$ & Observasi & $\begin{array}{l}30 \text { Oktober } \\
2018\end{array}$ & $\begin{array}{l}\text { Lembar } \\
\text { observasi }\end{array}$ & $\begin{array}{l}\text { Ibu hamil } \\
\text { dan suami } \\
\text { ibu hamil }\end{array}$ \\
\hline 3 & $\begin{array}{l}\text { Evaluasi pengetahuan } \\
\text { suami ibu hamil mengenai } \\
\text { anemia dan pencegahannya } \\
\text { serta mengukur kepatuhan } \\
\text { ibu hamil mengkonsumsi } \\
\text { tablet tambah darah }\end{array}$ & Kuesioner & $\begin{array}{l}31 \text { Oktober } \\
2019\end{array}$ & kuesioner & $\begin{array}{l}\text { Ibu hamil } \\
\text { dan suami } \\
\text { ibu hamil }\end{array}$ \\
\hline
\end{tabular}

3. Evaluasi Kegiatan

Evaluasi Kegiatan ini adalah untuk mengetahui pengetahuan suami ibu hamil dan kepatuhan ibu hamil dalam mengkonsumsi tablet tambah darah. Pengetahuan suami ibu hamil sebelum diberikan pendidikan kesehatan adalah 40,26\% dan setelah dilakukan pendidikan kesehatan adalah 75,80\%. Pendampingan oleh suami (one husband one client) setelah diberikan pendidikan kesehatan adalah $100 \%$. Kepatuhan ibu hamil setelah diberikan pendampingan adalah $100 \%$.

4. Penyusunan Laporan Kegiatan

Pada tahap ini disusun laporan kegiatan pelaksanaan pengabdian masyarakat.

\section{HASIL DAN PEMBAHASAN}

Produk yang dihasilkan dari kegiatan pengabdian masyarakat ini adalah pendidikan kesehatan tentang anemia dan pendampingan suami ibu hamil kepada ibu hamil ketika mengkonsumsi tablet tambah darah. Adapun langkah-langkah dan hasil kegiatan adalah sebagai berikut :

1. Persiapan yang meliputi penyusunan proposal dan seminar proposal di Poltekkes Kemenkes Tanjungpinang. Setelah Proposal diterima atau disahkan oleh Direktur Poltekkes Kemenkes Tanjungpinang selanjutnya kegiatan pengabdian masyarakat ini dilanjutkan pada tahap pelaksanaan.

2. Tahap pelaksanaan I yaitu diawali dengan pendekatan terhadap ibu hamil dan suami ibu hamil. Menyampaikan maksud dan tujuan kegiatan serta menjelaskan proses pengabdian 
masyarakat. Kegiatan ini mendapatkan respon yang baik dari ibu hamil dan suaminya. Kemudian dilaksanakan pendidikan kesehatan kepada suami ibu hamil mengenai anemia pada kehamilan dan pencegahannya. Kegiatan berjalan lancar dan mendapatkan respon yang baik.

3. Tahap pelaksanaan II yaitu melakukan kunjungan rumah ke rumah ibu hamil untuk memastikan bahwa suami ibu hamil melakukan pendampingan kepada ibu hamil ketika mengkonsumsi tablet tambah darah. Kegiatan berjalan lancar dan suami ibu hamil telah melakukan pendampingan.

4. Tahap Evaluasi yaitu melakukan evaluasi pengetahuan suami ibu hamil mengenai anemia dan pencegahannya serta evaluasi kepatuhan ibu hamil dalam mengkonsusmsi tablet tambah darah. Hasil evaluasi adalah terjadi peningkatan pengetahuan dan peningkatan kepatuhan ibu hamil dalam mengkonsumsi tablet tambah darah.

Hal yang mendukung kegiatan pengabdian masyarakat ini adalah dukungan dari Praktik Mandiri Bidan Fitriani dan ibu hamil beserta suami ibu hamil yang memmberikan respon positif dan berpartisipasi aktif selama kegiatan. Kendala yang terjadi diantaranya adalah cuaca hujan yang menghambat kunjungan rumah ke rumah ibu hamil sehingga beberapa ibu hamil tidak dikunjungi sesuai jadwal kunjungan. Tindak Lanjut dari kegiatan ini adalah akan direncanakan kegiatan pendidikan kesehatan menggunakan media yang lebih menarik berupa modul pada tahun 2019 .

\section{SIMPULAN}

Kegiatan pendampingan telah dilaksanakan dan mendapat respon yang baik dari ibu hamil dan suami ibu hamil. Terjadi kenaikan pengetahuan suami ibu hamil setelah dilakukan pendampingan serta terjadi peningkatan kepatuhan ibu hamil mengkonsumsi tablet Fe setelah dilakukan pendampingan.

\section{DAFTAR PUSTAKA}

1. Arisman. (2010). Buku Ajar Ilmu Gizi Jilid 2; Gizi dalam Dasar Kehidupan. Jakarta: Jakarta

2. Astuti. Dwi. (2014). Faktor yang berhubungan dengan kejadian anemia pada ibu hamil di Puskesmas Undaan Lor Kabupaten Kudus.University Research Collegium.123-128

3. Gibney, Michael J, Barrie M. Margetts, John M. Kearney, Lenore Arab. (2013). Gizi Kesehatan Masyarakat. Jakarta: Penerbit Buku Kedokteran EGC

4. Julianti.ED, Permanasari.Y, Aditianti. (2015). Pendampingan minum tablet tambah darah (TTD) dapat meningkatkan kepatuhan konsumsi TTD pada ibu hamil anemia. Jurnal Penelitian Gizi dan Makanan. 38(1).71-78.

5. Kemenkes RI.(2015). Profil Kesehatan Indonesia.Jakarta : Kemenkes RI.

6. Kozier. Erb, Berman. Snyder. (2010). Buku Ajar Fondamental Keperawatan: Konsep, Proses \& Praktik, Volume: 1, Edisi : 7, Jakarta : EGC.

7. Misaroh, Siti Ibrahim. (2011). Nutrisi janin dan ibu hamil. Yogyakarta : Nuha Medika

8. Morisky, et all. (2007). Predeictive Validity of a Medication Adherence Measure in an Outpatient Setting. The Jounal of Clinical Hypertantion. 10 (5).348-354. 
9. Neherta.M, Nelwati, Maisa.EA. (2010). Hubungan antara dukungan keluarga dengan kepatuhan konsumsi tablet Fe pada ibu hamil di wilayah kerja Puskesmas Nanggalo Kecamatan Nanggalo. Jurnal Keperawatan. 7 (2). 170-175.

10. Ningrum, (2009). Pemberian Tablet Fe Pada Ibu Hamil Untuk Mencegah Anemia. (http :///www.pemberian tablet fe pada ibu hamil untuk mencegah anemia.htm) diakses pada tanggal 24 Maret 2012.

11. Proverawati,Kusumawati. (2009). Buku Ajar Gizi untuk Kebidanan. Yogyakarta: Nuha Medika

12. Proverawati, Atikah.(2013). Anemia dan anemia kehamilan.Yogyakarta : Nuha Medika

13. Prawirohardjo, Sarwono. (2008). Ilmu Kebidanan. Jakarta: YBSP

14. Pusdatin Kemenkes RI.(2016). Situasi Gizi di Indonesia. Jakarta: Pusdatin Kemenkes RI

15. Tarwoto. (2007). Buku Saku Anemia pada Ibu Hamil, Konsep dan penatalaksanaan. Jakarta: Trans Info Media

16. Waryana, (2010). Gizi Reproduksi. Yogyakarta : Pustaka Rihama

17. Wiknjosastro, (2005). Ilmu Kebidanan. Jakarta: Yayasan Bina Pustaka Sarwono 